\title{
Let My People Go: the Exodus and Liberation Theology
}

\author{
PETER HEBBLETHWAITE
}

When Israel was in Egypt's land (let my people go!)

Oppressed so hard they could not stand (let my people go!)

Go down, Moses, way down in Egypt's land,

Tell ol' Pharaoh to let my people go!

\section{I}

In the mid-1980s a catechetical work produced by the French Catholic Church, Pierres Vivantes, fell foul of the Vatican's Congregation for the Doctrine of the Faith (henceforward CDF) and was officially abandoned. Pierres Vivantes (the 'living stones' which make up the gathering or ekklesia of which 1 Peter speaks) had proposed something very simple, yet to the CDF it was very heinous: to read the Old Testament not in the order it has come down to us in but in the chronological order of its presumed composition.

Admittedly, some hazards attend this judgment, but there is a scholarly consensus that the first book of the Bible was the account of the Exodus or 'way out' of slavery in Egypt. This was the single most important event in the formation of the Habiru or Hebrews as the people of Israel and the people of God. And it is recorded in the eponymous book.

The 'biblical theology' that flourished in the 1960 s accepted this basically Jewish account of the Exodus. The Vocabulaire de théologie bibliquel says that it marks the birth of the people of God even more than the promises to Abraham. The Exodus is a sign of Yahweh's love, and a pledge of the salvation which comes from him alone that will remain valid for the future: having delivered his people once from slavery in Egypt, he must be trusted to do so again whether the oppressors are the Assyrians (Isaiah 10:25) or the Babylonians (Jeremiah 16:14).

The Exodus or deliverance from the Egyptians was a mark of divine solicitude for this people. But Israel replied with ingratitude (Amos 2:10; Jeremiah 2:1-8). Thus a pattern of divine intervention in human history is established: the release from Babylonian captivity is presented as a second Exodus - and much of Isaiah is devoted to this theme. Moreover, there remains in Judaism a feeling that the desert life, marked by expectation and trust, before the promised land was reached, was somehow purer, nobler, more idealistic than anything that came afterwards.

So there is clearly more than one version of the Exodus. Norman K. Gottwald has discussed the four 'horizons' against which Jewish believers interpreted and reinterpreted the early 'poem' of Exodus 15. The political dimension is strongly stressed at the start (horizon 1) and remains clearly present or presupposed in horizons 2 and 3; but in the post-exilic version (4) it recedes into the background: 
The exodus-Israel ... [now] is not such much the national state, which had perished at the hands of Assyria and Neo-Babylonia, as it is the lawobservant community of Jewish believers who are defined not by territory or political structure but by a set of religious and ethical norms and practices which are set forth in the Torah and revealed during the exodus march from Egypt to Canaan.2

This, though congenial enough to the Vatican, was not what liberation theologians wanted to hear.

Their attention focused on the first 'horizon', where an oppressed people stood in need of liberation. For liberation theologians, the Exodus experience cannot be completely depoliticised so easily or so utterly, for it corresponds to some sort of historical event. The Exodus actually happened. The Pharaohs were real, ascertainable rulers. The date is difficult to determine but the Exodus was over by about $1225 \mathrm{BC}$. Here is how a modern 'secular' historian presents it:

The Exodus ... was a central episode in their history, and it has always been recognised by Jews as such, because it saw emerge for the first time, in transcendent splendour, the character of the unique God they worshipped, his power to deliver them from the greatest empire on earth and to give them a bounteous land of their own; and it revealed a multitude of his exacting demands which, in return, he expected them to meet.

Before they went to Egypt, the Israelites were a small folk almost like any other, though they had a cherished promise of greatness. After they returned, they were people with a purpose, a programme and a message to the world. ${ }^{3}$

Now this historical event, so central to Jewish religion, is constantly evoked by liberation theologians because it illustrates so perfectly that union of the religious and the political they advocate.

To ask whether Moses was a religious or a political leader is in their eyes to ask a silly question. He was manifestly both. Indeed, he was more clearly a political leader than was Jesus of Nazareth - which is why some liberation theologians like Segundo Galilea actually prefer Moses as a model of the political leader.

It is true that liberation theologians make use of the 'broad brush' approach to scripture. They do not claim to be biblical theologians and content themselves with developing the dominant theme of the Exodus, and flanking it by the prophetic critique of society in Amos and Jeremiah and Jesus' conflict with the Jewish authorities. Gottwald remarks that in the base communities one finds 'a devotional regard for scripture ... that displays a predisposition to accept the Bible as authoritative without intensive demonstration, ${ }^{4}$ or indeed any demonstration at all. The important thing is 'to find my situation now reflected in the Bible'. At this point the Bible 'comes home'.

Thus the Exodus, the central event in Jewish thinking about history, foreshadows the transformation that is urgently needed in Latin American society today. One of the most remarkable statements of the CELAM meeting at Medellín in 1968 comes in the introduction to its Final Document. Pope Paul VI had been present at the start of their conference, and had then departed, saying in advance that he would accept their decisions. The result is that a long passage from his encyclical letter Populorum progressio, on how the 'more human' should be the norm of Catholic social teaching, is awkwardly, indeed clumsily, introduced with the following lead: 'Just as Israel of old, the first people [of God] felt his saving presence when God delivered them from 
the oppression of Egypt by the passage through the Red Sea, so also the new people of God...' Now whatever Moses had in mind, it was unlikely to have been the more human, ever more human, post-Jacques-Maritain considerations that entered into the admirable encyclical Populorum progressio. The point is that the Latin American bishops should already feel obliged to set Paul VI's renewed neo-Thomism in some sort of biblical context, however approximate or rough and ready.

After that the 'tradition' was established. The classic text which assigns an exemplary role to the Exodus comes naturally in Gustavo Gutiérrez's Notes Towards a Theology of Liberation of 1971. The 1960s had been declared by President John F. Kennedy 'the decade of development', in which prosperity would trickle down from above. In fact it had not trickled down at all, and the disparities between rich and poor were rather increased. Populorum progressio had said that 'development is the new name for peace'. Fine, if it happened; but it did not.

At this point 'Marxism' in a broad sense and 'Christian faith' combined in their analysis of what was happening. Latin American Marxists explained the 'underdevelopment' of their continent as an aspect of their dependence on the capitalist economies of the developed world. Their 'underdevelopment' was, in other words, functional, endemic and part of the world system of exchange. This view was classically and brutally stated by the Marxist thinker André Gunder Frank: 'Development and underdevelopment are two sides of the same coin'. 6

So post-Medellin Latin Americans began to translate the Christian doctrine of 'salvation', a metaphor taken from health (salus), and to prefer to call it 'liberation'. 'Redemption', another metaphor taken this time from buying people out of slavery, was likewise translated as 'liberation'.

Once these steps had been taken, the Exodus was the obvious paradigm for what the Latin Americans wanted to do. Here is Gutiérrez:

The liberation of Israel is a political action. It is the breaking away from a situation of despoliation and misery and the beginning of the construction of a just and comradely society. ... The Exodus is the long march to the promised land in which Israel can establish a society free from misery and alienation. Throughout the whole process the religious event is not set apart. It is placed in the context of the entire narrative, it is its deepest meaning. . . The liberation from Egypt, linked to and even coinciding with creation, adds an element of capital importance: the need and the place for active human participation in the building of society.... The Exodus experience is paradigmatic. It remains vital thanks to similar historical experiences which the People of God undergo.

The reason - or one of the reasons - why the Exodus commends itself to liberation theologians is that it overcomes the 'dualism' they seek to denounce. There is not a 'spiritual realm' on one level and practical political action or praxis on another. There is only one world in which liberation can occur.

Note, too, the Maxist flavour of Gutiérrez's account. The dependency analysis led him down this path. He is engaged upon 'the construction of a just and comradely society. ... The Exodus is the long march to the promised land in which Israel can establish a society free from misery and alienation.' This was not enough to convince Alistair Kee that Gutiérrez is a serious student of Marx, ${ }^{7}$ but it was enough to alarm the Vatican and persuade the CDF to take action against him. 
Now liberation theology has been associated with Latin America almost exclusively and when exported to Asia or Africa has been transformed in ways that are beyond the scope of this article. ${ }^{8}$ 'Do not we in Poland have the right to have our own liberation theology?' asked Halina Bortnowska in 1985. Poles were certainly labouring under the oppression of martial law and in need of delivery from it. But because the word 'liberation' was used by communists (as in 'national liberation movements' of the post-colonial era) and because their own 'liberation' in 1944-5 had proved a hollow sham, Poles were disinclined to use this tainted vocabulary. Liberation! How many crimes have been committed in your name! So many people had been enslaved in the name of liberation.

This was the judgment of Pope John Paul II in the first Vatican instruction On Certain Aspects of Liberation Theology (3 September 1984):

A key fact of our time ought to evoke the reflection of all those who would sincerely work for the true liberation of their brothers: millions of our own contemporaries legitimately yearn to recover those basic freedoms of which they were deprived by totalitarian and atheistic regimes.

So this theme goes right to the top of the papal agenda. It is 'a key fact of our time': not something we can think about from time to time.

The instruction goes on even more fiercely: 'This shame of our time cannot be ignored: while claiming to bring them freedom, these regimes keep whole nations in conditions of servitude which are unworthy of mankind.' Anyone suspected of supporting Marxists or even learning anything from them, such as liberation theologians, the Sandinistas in Nicaragua or the martyred Archbishop Oscar Romero, are deluded like Lenin's 'useful idiots'. The phrase 'this shame of our time' was the Vatican equivalent of President Ronald Reagan's 'evil empire' speech which came a few months later.

There was at this stage an accidental overlap between the policies of the USA and of the Vatican Secretariat of State, particularly in Central America. General denunciations of violence did not seem to apply to the Contras, who were attacking Nicaragua wearing papal badges and claiming to be crusaders. The Archbishop of Managua, Obando y Bravo, was made a Cardinal in 1985, to strengthen his arm. On his return he stopped over in Miami, said Mass for the Contra chiefs and fundraisers, and received an effusive telegram of congratulations from President Reagan.

The 1984 instruction also deals with the Exodus, an event, it rightly says, that 'will never be effaced from the memory of Israel':

The exodus, in fact, is the fundamental event in the formation of the chosen people. It represents freedom from foreign domination and slavery. One will note that the specific significance of this event comes from its purpose, for this liberation is ordered to the foundation of the people of God and the covenant cult celebrated on Mt Sinai. That is why the liberation of the exodus cannot be reduced to a liberation which is principally or exclusively political in nature. Moreover, it is significant that the term freedom is often replaced in scripture by the very closely related term redemption. ${ }^{9}$

This neatly reverses the procedure of liberation theologians: they translated redemption as liberation to make it more vivid; it is now translated back as redemption to make it more 'religious' or 'spiritual'. So the Vatican instruction can conclude on this 
point: 'In this exodus experience God is recognised as the liberator. God will enter into a New Covenant with his people. It will be marked by the gift of God's spirit and the conversion of hearts.' 10 At this point the 'recuperation' of liberation theology is almost complete.

\section{III}

Poland was the first country to shake off communism because it was the first country to have a mass workers' movement, Solidarność, which challenged the communists' right to rule. Leszek Kolakowski maintained that Marxism in Poland had long ceased to have any intellectual or cultural content and had simply become a mechanism for retaining institutional power. Otherwise it was completely alien. Yet a regime not based on the consent of the governed is doomed, sooner or later. You can do anything with bayonets, said Aldous Huxley, except sit on them.

In the autumn of 1981 - it is said - General Wojciech Jaruzelski, then first secretary of the Polish United Workers' Party, was taken by plane to witness the Soviet troops massing on Poland's eastern frontier, and told that unless he cracked down on Solidarność they would invade. A 'Polish' solution was preferable to a Soviet one. Hence martial law was imposed on 13 December 1981. Jaruzelski's 'patriotism' was recognised by some of his political opponents and in particular by Cardinal Józef Glemp, who felt the need to restrain hotheads like Fr Jerzy Popieluszko, who were intent on confrontation and indeed martyrdom.

The third papal visit to Poland in 1987 was the final delegitimisation of Jaruzelski. Pope John Paul talked as though the communist authorities were simply holding on by their fingertips with only the appearance of real power. There was a complete break between the pays légal and the pays réel.

In June 1987 there was a fiery exchange between Jaruzelski and the Pope as they said farewell at the airport. The President said (I paraphrase): 'It is all very well for you to have this romantic vision of Poland, but you are going back to Rome: I have to stay here and govern Poles.' Did he mean Poles were ungovernable?

Meanwhile Mikhail Gorbachev had changed the geopolitical realities of Poland. The 'Sinatra Doctrine' - the nations of Central Europe must do it their way removed the old fear of invasion from the East. The grounds for military rule in Poland were thus cut away. It no longer made sense for Solidarnosić to remain illegal and underground. The round table of spring or Lent 1989 resulted. Some hindsight is needed to see the events with such clarity.

\section{IV}

In his attitude to Latin America Pope John Paul's views were no different from those of other Polish intellectuals. I say 'intellectuals' rather than theologians or churchmen, since at that time little was known of Polish theology abroad and Polish priests who travelled tended to confine themselves to Polonia, that wider Poland to which all exiles belong. But the 'Clubs of Catholic Intellectuals' (KIK) meant that in the major cities of Poland there were informed laypeople who were well-read in the inter-war Catholic tradition (Jacques Maritain and Emmanuel Mounier were the names most frequently evoked). They had created a whole 'alternative culture'.

Their faith had kept them out of a conventional Polish university education. Yet they did not find the lack of a university education any great loss, since academic posts depended on political conformity and to be spared compulsory large doses of 
'Marxism-Leninism' was a blessed relief. They educated each other. Tadeusz Mazowiecki, Jerzy Turowicz, Halina Bortnowska, Marek Swarnicki and many others kept alive the flame of Polish culture throughout the years of communism. Cardinal Stefan Wyszyński, the primate, who wanted a well-regimented church and a docile laity, was often at odds with them. But they found in Karol Wojtyla, Archbishop of Kraków, an ally, a mentor and an example.

Marek Swarnicki, poet and editor of the plays of Karol Wojtyla (one he rejected as 'too obscure'), was sent by his cardinal to a Pax Romana meeting in Mexico in the late 1960s. On his return he gave him a private report. They both found the Latin American fascination with Marx and the young Marx naive, alarming, uncritical, bewildering, inaccurate and above all theoretical. The Poles were not interested in the dependency explanation of underdevelopment, since their own relative 'underdevelopment' could be explained by Marxism.

So for all the talk in Latin America about the union of teoria and praxis, the Poles thought the Latin Americans had the teoria, which cost them nothing, while the Poles experienced the praxis, which cost them a lot, their livelihoods if not their lives. The Latin Americans failed to judge the tree of Marxism by its bitter fruits.

In talking about 'Poles' and 'Latin Americans' I am of course simplifying. Yet Polish Catholic intellectuals displayed a remarkable consistency. They represented a political and theological culture that was the same wherever you cut into it. It resembled what Graham Greene said of a stick of Brighton rock: it read Brighton all the way down; the Polish rock read Kraków all the way down. This was not a matter of slavish conformity (such as Wyszyński might have demanded) but of a common Christian culture (which Wojtyla both represented and promoted).

One can test this by asking what Polish intellectuals thought of 'freedom' and 'liberation'. Let me quote from a text which Helmut Juros, a generation younger than the names previously mentioned, prepared for the first meeting of the European Society for Catholic Theology which met in Stuttgart on 5-9 April 1992:

Under communist rule practically every Pole knew that he was free in his inner being, free because he was a person, free because he retained a personal dignity that he did not have to earn - that is, it was not something the state conceded to him. Because of that he was ultimately 'free', even though he had to live under 'unfree' conditions.

To be free, he did not have to be liberated by the collapse of 'socialist conditions'. It was rather that his individual, Christian-oriented autonomy endowed him with a freedom that would eventually win through in society and would thus overcome the political 'unfreedom' of the state, and free itself and others from dictatorship so that a 'free life' would be possible once more. ${ }^{11}$

Juros was alluding in that last sentence to the slogan of the nineteenth-century revolts against the Russians in Poland: 'For our freedom and yours!'

This was, as it turned out, the successful slogan of Solidarnosí as well. The Poles were the first to 'free themselves' from communism in the spring of 1989. Central Europe and then the Soviet Union itself rushed through the breach the Poles had opened.

So the Polish conception of freedom involves an inner freedom, a freedom of the spirit, which does not depend on outward circumstances. The freest place of all could be a prison. There is an intangible, inalienable human essence that no jailer can touch. 'Stone walls do not a prison make, nor iron bars a cage.' This is a human perception, 
but I think we can say that the Slavs have understood it better and proclaimed it more dramatically than any other people. Witness Aleksandr Solzhenitsyn on the pseudofreedoms of the USA compared with the spiritual freedom he knew as a political prisoner. ${ }^{12}$

Pope John Paul II adds the gloss that freedom of spirit, grounded in inalienable human dignity, depends ultimately on freedom in the Holy Spirit. His most disregarded encyclical, Dominum et vivificantem (18 May 1988, Pentecost Sunday), establishes this link with the utmost clarity:

When, under the influence of the Paraclete, people discover the divine dimension of their being and life, both as individuals and as a community, they are able to free themselves from the various determinisms which derive mainly from the materialistic bases of thought, practice and related modes of action. In our age these factors have succeeded in penetrating into man's innermost being, into that sanctuary of the conscience where the Holy Spirit continuously radiates the life and strength of new life in the "freedom of the children of God'.13

Eastern Orthodox Christians frequently reproach the 'West' with neglecting the Holy Spirit. Perhaps part of the Slav Pope's mission is to mediate the 'Oriental' understanding of the Holy Spirit in a language the Latin 'West' can understand.

This is the Slav version of 'liberation theology'. Its key text is: 'Where the Spirit of the Lord is, there is freedom' (Romans 8:2). Once again, Solzhenitsyn applauds.

What I am calling 'the Slav version of liberation theology' finds its most complete expression in Christian Freedom and Liberation, the second CDF instruction (dated 22 March 1986). This document is an outright attack on the Enlightenment for its false notion of freedom as merely freedom from external constraint or compulsion. Moreover, both Marxism and liberalism are seen as the intellectual heirs of the Enlightenment. In an article significantly called 'St Peter and John Stuart Mill' Marcin Król argues that a religion of revelation cannot be combined with liberal relativism. ${ }^{14}$ The CDF instruction defines true freedom as 'interior mastery of one's own acts, and self-determination', 15 which is clearly incompatible with freedom defined in Mill's terms as 'not being encroached upon by anyone else'.

How, then, will the Exodus be interpreted by the CDF? The 1986 instruction offers a more developed treatment than its 1984 predecessor:

In the Old Testament the liberating action of Yahweh, serving as a model and reference for all others, is the Exodus from Egypt, 'the house of bondage'. When God rescues the people from hard economic, political and cultural slavery, he does so in order to make them, through the Covenant on Sinai, 'a kingdom of priests and a holy nation' (Exodus 19:6). God wishes to be adored by people who are free. All the subsequent liberations of the people of Israel help to lead them to this full liberty that they can find only in communion with their God.

The major and fundamental event of the Exodus, therefore, has a meaning which is both religious and political. God sets the people free and gives them descendants, a land and a law, but within a covenant and for a covenant. One cannot therefore isolate the political aspect for its own sake; 
it has to be considered in the light of a plan of a religious nature within which it is integrated. ${ }^{16}$

The implication is that liberation theologians have 'isolated the political aspect for its own sake', and thus completely secularised the Exodus.

Political consequences follow from this view of freedom as self-determination and the gift of the Holy Spirit. First, the 'freedom' and the 'freedoms' of Western Europe are relativised. If the 'West' is ruled by 'the conditioning and mechanisms' which ultimately 'deprive the human spirit of its being and life, ${ }^{17}$ then it too stands condemned. One of the most striking features of Sollicitudo rei socialis, the social encyclical of 1987, was that it denounced the parallel imperialisms of 'collectivism', dominated by a thirst for power, and capitalism, dominated by a thirst for profit and damn the social consequences.

This is traditional Catholic social doctrine, once described as 'neither left nor right'. Down goes communism. The right rejoices, but too soon, for down go Thatcherite individualism and Reaganomics too. The immediate implications of this plague-onboth-your-houses theory is that the church was most unlikely to present the defeat of communism as the victory of capitalism. In Centesimus annus, which appeared in 1991, after the events, while the 'anthropological error' of Marxism is denounced once again, the idea that the naked play of unimpeded market forces alone can produce social justice is equally repudiated.

\section{VI}

The events of 1989-91 were a famous victory for something. If it was not capitalism, then what? The conviction that God had a hand in it was expressed in a variety of ways. On Sunday 9 June, the last day of Pope John Paul's fourth visit home, Cardinal Józef Glemp compared the visit to the crossing of the Red Sea by the Israelites. Pope John Paul liked this comparison so much that he repeated it three times in the course of the day.

We should not press Glemp's use of the Exodus for a significance it did not possess. $\mathrm{He}$ was not doing an act of exegesis any more than the liberation theologians were. $\mathrm{He}$ was not joining in the debate about whether the Exodus was a political event with religious meaning or a religious event with political meaning. Cardinal Glemp is not that subtle. His main point was simply that God had 'shown his power to deliver them from the greatest empire on earth and to give them a bounteous land of their own' (to quote Paul Johnson again).

One reason for not pressing the Exodus image too closely was that a Moses figure was required for the Exodus, and the only person at all capable of playing that role was Lech Wał̧̧sa, already beginning to display some unMosaic qualities. A second reason for not pursuing the image further was, of course, that the crossing of the Red Sea was not the end of the affair, and that another forty years were spent wandering in the desert, with much grumbling and going astray. So the Exodus was only inaugurated liberation, not yet realised liberation. A third reason for dropping Exodus imagery was that it had the political content that the Latin Americans had correctly perceived.

So there were, henceforward, only glancing references to the Exodus theme. Yet the question it posed could not be eluded. 'God was mightily at work in China' was the title of an SCM conference in the 1970s. With more plausibility, God had been mightily at work in Europe in 1989-90. But how? This question was put on the agenda of the special Synod on Europe: 
Europe stands at a crossroads in its history. What are the 'signs of the times' to be discerned in recent events by which Divine Providence challenges the church and its pastors? In your opinion, what is the Holy Spirit's message for the church in Europe?

European Bishops were supposed to submit their reflections in advance of the Synod to be processed.

These 'responses' were not officially published. But the answer of the Scottish Bishops came into my hands and, since it is very typical, I will quote it:

The 'recent events' referred to are the extraordinary happenings in Central Europe which have led to the disintegration of the communist regime in one country after another, in a practically bloodless series of coups the likes of which Europe has never seen before. Václav Havel, the new President of Czechoslovakia, called these events 'a miracle'. Cardinal Paul Poupard and others have referred to these recent events as a kairos, i.e. a special moment when God visits his people with an opportunity for repentance and conversion, for change and decisive action; a time of action; a moment of truth, a crisis....

The fact that Christians played a unique role in the downfall of communist regimes in the oppressed nations of Europe means that the Christian churches, and the Catholic Church in particular, must interpret the changing European scene by reading the signs of the times in the light of faith and discern the hand of God behind the web of history. ${ }^{18}$

This is well put, but it does 'spiritualise' the events. Perhaps it could be called a more 'contemplative' approach. Though it speaks of the need for 'decisive action' it does not give any hint as to what this might be. God is at work behind the web of history, not within it, as the Latin Americans would insist. Talk of 'miracle' and 'kairos' cries out for some mention of the Exodus; but none is forthcoming.

\section{VII}

In the final chapter of his Apologia pro vita sua John Henry Newman regards it as selfevident that innovation must come from outside Rome while Rome has an essentially 'conservative' function:

It is individuals, and not the Holy See, that have taken the initiative, and given the lead to the Catholic mind, in theological enquiry. Indeed, it is one of the reproaches urged against the Roman Church that it has originated nothing, and has only served as a sort of remora or brake on the development of doctrine. ${ }^{19}$

On 12 April 1986, a letter from Pope John Paul was read out to the 320 Brazilian bishops which declared that 'liberation theology was not only opportune but useful and necessary'. The bishops hugged each other for joy and sang alleluia. Were they being entirely naive? For all its conservatism, Rome learns from that which it opposes, and eventually 'takes on board' the view of its critics - but only after it has winnowed them scrupulously. And the Pope has made it clear often enough that the 'liberation theology' that is acceptable to the Vatican is one that has been purged of Marxism. 


\section{Notes and References}

I Xavier Léon-Dufour SJ (ed.), Vocabulaire de théologie biblique (Cerf, Paris, 1962), under 'Exode'.

2 Norman K. Gottwald, 'The Exodus as event and process: a test-case in the biblical grounding of liberation theology', in Marc H. Ellis and Otto Maduro (eds), The Future of Liberation Theology: Essays in Honor of Gustavo Gutiérrez (Orbis, New York, 1989), p. 258.

${ }^{3}$ Paul Johnson, A History of the Jews (Weidenfeld and Nicolson, London, 1987), p. 23.

${ }^{4}$ Gottwald, op. cit., p. 252.

s At this point a phone call on another matter led my Brazilian interlocutor to say: 'People keep on misunderstanding liberation theology because they do not understand that it is not like western academic theology.' In the long run, that is not much of a defence.

6 See Arthur F. McGovern SJ, 'Dependency theory, Marxist analysis, and liberation theology', in The Future of Liberation Theology, p. 272.

7 Alistair Kee, Marx and the Failure of Liberation Theology (SCM, 1990). For Kee, liberation theology is insufficiently Marxist.

${ }^{8}$ The work of EATWOT - the Ecumenical Association of Third World Theologians - would have to be studied in order to deal with Asian and African theologies. See Aloysius Pieris SJ, An Asian Theology of Liberation (Orbis, New York, 1988).

9 Text in Alfred T. Hennelly (ed.), Liberation Theology: a Documentary History (Orbis, 1990), p. 397.

10 loc. cit.

"Helmut Juros, Polens Politischer Katholizismus heute, p. 5.

12 It has often been remarked that Solzhenitsyn, in his retreat in Vermont, reproduced prison conditions with defensive walls and expensive electronic equipment to keep him free from intrusion.

13 Dominum et vivificantem, 60.

14 Marcin Król, 'Der heilige Petrus und John Stuart Mill', Transit: Europäische Revue (Vienna), no. 3, Winter 1991/92, p. 100. He makes the important point that Adam Michnik's book Église, Gauche, Dialogue, published in Paris in 1977, reposed upon the illusion that the opposition to communism in Poland was based upon 'liberalism'. It was not, as events have shown.

15 Christian Freedom and Liberation, no. 27.

16 ibid, no. 44.

17 Dominum et vivificantem, 60.

18 Bishops' Conference of Scotland, European Synod of Bishops, Response to Guideline Questions (Catholic Press and Media Office, 5 Vincent Place, Glasgow).

19 John Henry Newman, Apologia pro vita sua, p. 265. 